\title{
The Development of Creative Clinic Model In University: Issues And Implications
}

\author{
Andri Zainal $^{1 *}$, T. Citra Nisa Farza ${ }^{2}$, Kustoro Budiarta $^{3}$ \\ Faculty of Economics, Universitas Negeri Medan, Indonesia ${ }^{1,2,3}$ \\ *andrizainal@unimed.ac.id
}

\begin{abstract}
Academics as part of a community of scholars in either higher education institutions or research institutions particularly have a large role in developing the creative economy. The synergy between tertiary institutions and Micro Small Medium Enterprises (MSMEs) through a one to one approach is expected to boost the creative economy sector that has gained significant interest from both business actors and the government due to its enormous economic potential. This qualitative study aims to descriptively analyze the needs of MSMEs in Medan Municipal City toward developing and establishing the creative economy clinical model at LPPM Unimed. The result of the analysis depicts profiles of the business owner, the business profiles and the business performance from MSMEs in Medan. The importance of identifying the needs of MSMEs is based on the theory of Know Yours Customers (KYC) strategies underlining the urgency of MSMEs to provide excellent service for clients by recognizing requirements expected by their service users accurately.
\end{abstract}

Keywords: Creative Economy, SMEs, Creative Economy Clinic, Quadruple Helix, University

\section{Background}

The creative industry is one of the industrial fields that has great opportunities to develop rapidly in the industrial revolution 4.0 era. This is due to the incorporation of the recent technology utilized in majority creative industry related-sectors optimizing the creativity and thinking ability of the perpetrators. This opportunity is certainly the right moment for the government, especially Indonesia to strengthen the foundations of the economy, especially by making the creative economy a priority given that the creative economy relies more on creative human resources because human creativity comes from the power of thought which is the basis for creating innovation in face greater competitiveness or market competition in the current eruption era. Furthermore, the concept of a creative economy is getting more attention in many countries because it can make a real contribution to the economy for developing countries to raise, grow and develop with an inclusive and sustainable level of economic growth $[1,2,3,4]$. 


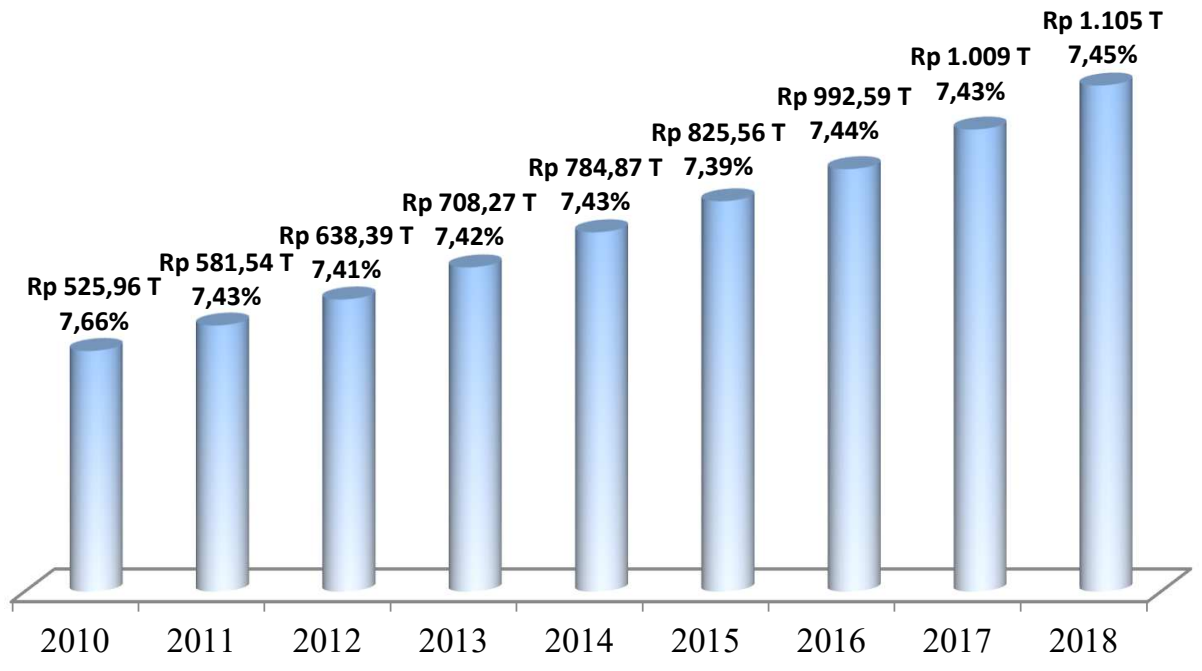

Source: The Indonesia's Creative Economy Statistic

Fig 1. GDP from Creative Economy Sector and Its Contribution to National GDP from 2010-2018

The creative economy in Indonesia has given a good contribution to help the national economy. This can be seen from the above figure that shows a positive trend in the development of the Gross Domestic Product (GDP) of the creative economy in Indonesia. The GDP of the creative economy sector from 2010-2018 consistently rose to IDR 1,105 trillion in 2018 which is equivalent to 7.45 percent of the total Indonesian economy. In comparison to other countries, the contribution of Indonesia's creative economy sector to the national GDP is not exactly small. The figure of 7.43 percent in 2017 places the contribution of the creative industry sector in Indonesia above similar performances from other countries such as Canada (4.63 percent), Singapore (5.90 percent), Philippines (5.24 percent) and Russia (6.12 percent). In 2016 particularly, Indonesia ranked as the third-largest creative economic contribution to the national economy, below the United States (11.12 percent) and South Korea (8.67 percent). The share of Indonesia's creative economy GDP is 7.44 percent greater than Russia, Singapore, the Philippines, and Canada. This figure also indicates the level of the Indonesian economy experiencing rapid development in the scope of the creative economy. One of them is caused by the widely used of information technology that makes opportunities and improvement of the creative economy faster $[5,6]$.

The growing development of digital technology affects the current shift in the structure of the creative economy. The creative economy sector is facilitated by the relationship among the government, intellectuals, entrepreneurs and the community that later called the 'quadruple helix' model. This model has performed as the main actor driving the birth of creativity, ideas, science, and technology that is vital for the growth of the creative economy in Indonesia. A close relationship, mutual support, and symbiosis among the four actors establishing the foundation and pillars of the creative economy model that will last in the long-term period [3]. 
Apart from the government, academics as part of the community of scholars in higher education institutions and research institutions, have a larger role in developing the creative economy. Academics here (researchers and lecturers) have a role as agents who disseminate and implement science, art, and technology. They are also expected to shape constructive values for the development of the creative economy in society. The majority of researchers believe and state that the university's key role in the creative economy lies in optimizing its ability to transfer the research outcomes to industry, generating new inventions and technology spin-offs in the form of startup companies [3,7].

Accordingly, the role of universities through intellectual transfer will strengthen the formal and informal bases of innovation. In particular, universities can mature innovation concepts and also have the capacity to disseminate information with international networks [3]. In line with this initiative, there has been a movement in the United States and throughout the world to make universities as the 'engine of innovation' $[9,10,11]$ that further increase their ability to commercialize their research [7].

In the era of disruption with more complex demands and challenges for creative economy actors - especially for MSME players who have issues in the knowledge of applying technologies - the real contribution of tertiary institutions as strategic facilitators can help stakeholders (MSMEs, governments, and companies) in elevating the performance of the incountry creative economy sector. The number of studies has underlined this phenomenon. Nicholaides [12] analyzes the role of universities in South Africa; Kasim [13] conducted a similar study on how universities in Malaysia have formed an entrepreneurial agenda; Faggian [14] discussed the importance of universities as providers of local MSME research and development; Darwish [15] conducted a study of the role of universities in developing SMEs in Bahrain; Ghina [16] examined the effectiveness of entrepreneurship education in higher education institutions in Indonesia; Comunian [17] conducted a study of the relationship between universities and the creative economy with analysis on creative graduates, knowledge transfer and regional impacts; and Bomani [18] examine the role of higher education institutions in the development of SMEs in Zimbabwe. In general, research findings indicate that tertiary institutions play a very important role in optimizing the performance of SMEs through training, technology transfer, business incubators, research, and research commercialization.

Universitas Negeri Medan (henceforth called as UNIMED) has carried out its role in encouraging the development of MSMEs, especially in the City of Medan. Lecturers as researchers and community service professionals have conducted many research studies and applied the outcomes of studies to the community on a one to one approach, namely through the Community Partnership Program (PKM). The Institute for Research and Community Service at Medan State University (LPPM Unimed) is actively seeking to increase the potential of MSME entrepreneurs who have become partners of LPPM Unimed to become more innovative and independent MSMEs. Even though universities have a very strategic role as stakeholder facilitators in the development of the creative economy, the fact is that in many cases MSMEs still face various obstacles. Head of North Sumatra Province Cooperative and UKM Office, Drs. Amran Utheh, MAP stated several MSME related obstacles: (1) the low quality of HR management of MSMEs; (2) the low growth of MSMEs; (3) lack of MSMEs that have access to capital; (4) low competitiveness of micro and small businesses; and (5) limited product marketing and MSME partnerships. Meanwhile, the Minister of Transportation, Budi Karya Sumadi, revealed that one of the limitations of solving MSME problems was because MSME actors were lagging in the use of technology. SMEs are still not 
optimally engaging in digitalization opportunities as shown on the statistic records that until the end of 2018 only 5 percent of MSMEs in Indonesia go digital $[19,20]$.

The role of universities as one of the actors driving the creative economy in a country has not run effectively. The existence of a forum or space for the creative economy on campus is still not optimal in terms of accelerating the development of the creative economy caused by various factors related to the stagnation of the ideal ecosystem. Some evidence to support this statement includes: the lack of ability of lecturers to provide new paradigms related to the importance of entrepreneurship, entrepreneurship partnerships, and tertiary institutions have not operated effectively, lack of collaboration between tertiary institutions and MSMEs, and collaboration with financial and non-financial institutions limited [16].

Based on the phenomena and findings of the research, the quality of university partnerships with MSMEs still needs evaluation to provide the maximum contribution. For this reason, LPPM Unimed continues to make every effort to design a variety of strategic work programs to support the growth and development of MSMEs that are fostered by developing a creative economy clinical model specifically to meet the demands of conditions in the 4.0 industrial revolution era and in welcoming the era of society 5.0.

This descriptive qualitative study analyzes the identification of the needs of MSMEs for the follow-up mapping needed in the development of a creative economy clinical model at LPPM UNIMED with the formulation of the problem:

- Research Problem 1: What are the problems and obstacles faced by MSMEs in Medan in the current conditions?

- Research Problem 2: How can the effectiveness of creative economy clinic services support and encourage the success of MSMEs in Medan?

- Research Problem 3: What are the indicators that explain the needs of MSMEs as the development of a creative economy clinical model?

Thus, the objectives of this study are intended to:

1. To find out the problems and constraints of MSME in Medan.

2. To determine effective factors in encouraging the practice of MSMEs in accordance with their effectiveness criteria.

3. To determine the mapping of indicators identifying the needs of MSMEs in Medan as a preliminary study of the development of a creative economy clinical model.

\section{The Link Amongst University, Creative Economy And Clinical Model}

\section{The Relationship Between The University and Creative Economy}

Universities have long played an active role in research and technology development, especially in developed countries. In the era of the industrial revolution 4.0, universities are also expected to play a key role in regional development. The role of traditional universities whose main mission is research and teaching has been replaced by entrepreneurial universities that are more actively engaging in income-generating. These entrepreneurial universities are also widely regarded for their competence in increasing economic viability through technology transfer, commercial transfer, innovation, spin-off company generation, and direct involvement in regional development [21].

More specifically, Alexander and Eugeniy [8] state that universities are agents of economic and technological development. Universities offer more than knowledge and service provision hence they should focus on their third role, which includes fostering knowledge that is regionally embedded, co-created, and shared [7]. Plechero [22] and Piterou and Birch [23] 
further underline for universities taking more initiatives in building a strong relationship between universities and SMEs through direct and informal contact.

Indonesia's universities have taken in charge of improving the development of the creative economy sector, especially for those contributing to the MSMEs. The respective roles are relevant to the three main universities' roles (called as the Tri Dharma of Higher Education in the local term) set for: (1) encouraging the birth of Indonesia's creative generation with a mindset that supports the growth of initiative and works in the creative economy from a formal education; (2) actualizing high-quality research to provide input on creative economic development policy models and instruments needed, and produce technologies that support the workings and efficient use of resources as well as making a greater national creative economies competitiveness; and (3) establishing more innovative and independent societies that support the growth of the national creative economy through conducting community service engagements $[1,24]$.

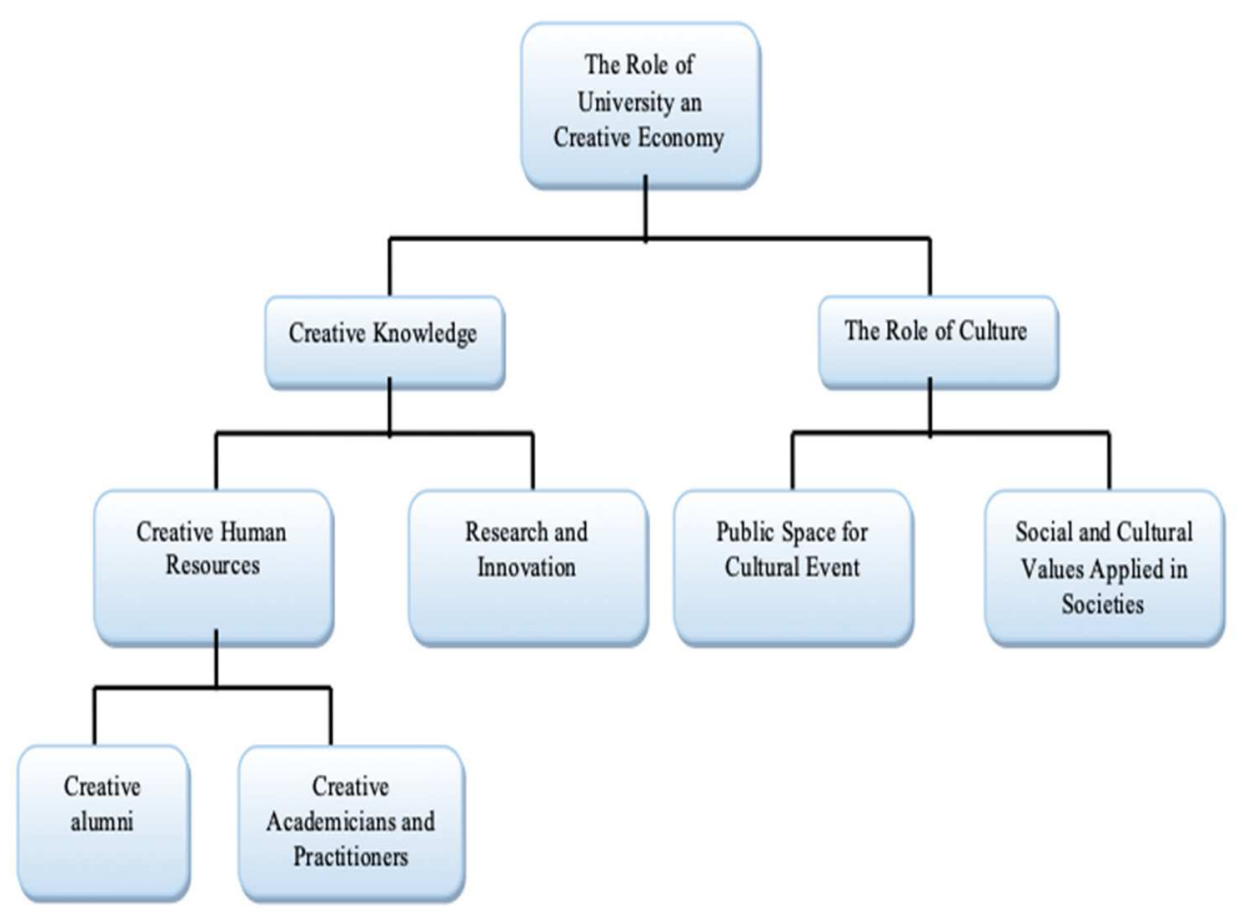

Source: Comunian dan Gilmore in Florida et al., 2006

Fig 2. A Mechanism of the Relationship between University and Creative Economy

From the above figure, it is known that the interaction between universities and the creative economy fosters creativity, innovation, and technology transfer, which is very important for economic development and national competitiveness [15,25]. Universities have also commercialized research outcomes [8] and can be freely accessed via the Internet [30]. 


\section{The Creative Economy Clinic In Campus}

Creativity is the main capital in facing global challenges. The form of the creative economy always comes up with a unique added value, creates its market, and manages to absorb labor and economic income. To establish a solid creative economy sector, number of high-quality human resources with innovative power and creativity are needed. However, in addition to the need for quality human resources, the development of a creative economy also requires space to explore ideas, work, as well as self-actualization and creative ideas [1].

In developed countries, the formation of creative spaces has led to creative cities supported by an existing conducive atmosphere for the community to foster their creativity. Besides, creative studios are also served as a forum for creative economics that can be formed. The concept of the creative studio is an idea given by University of Selamat Sri academics to provide a forum for business people or communities in developing creative economic activities, managing current potentials, producing goods or services, education, promotion, packaging, and collaborating with various parties [5].

In responding to the situation, LPPM Unimed has also provided space or a place for the development of creative economic ideas through the creative economy clinic that complementing the existing Community Partnership Programs (PKM). Universities and lecturers play a role as facilitators who help stakeholders to enhance the development of the creative economy, especially assistance to MSMEs around the City of Medan. This creative economics clinic is intended to mediate and encourage MSMEs as local partners of LPPM UNIMED. It is also performed as a laboratory for MSME partners' applying relevant technology in fostering the needs for innovation and digitalization.

Likewise, there has been none of the research conducted in both studying the existence of the creative economy clinic and its influence on accelerating the development of the creative economy for local MSMEs. This is not only caused by various factors related to the stagnation of the ideal ecosystem, to name a few is a weak governance system. Based on the existing limitations, LPPM Unimed conducts a study related to the development of an effective creative economy clinic model toward providing optimal services and assistance for MSMEs.

\section{Research Method}

This research uses a quantitative descriptive approach started by reviewing theories and empirical studies to obtain a descriptive picture related to the potential of the creative economy sector and the role of tertiary institutions as the mediator for MSMEs. Accordingly, we analyzed relevant problems faced by MSMEs in the era of the industrial revolution 4.0. The output of this step is used to identify the needs of MSMEs towards developing an effective clinical economics clinical model for the development of technology-based MSMEs. The research concludes by developing several conclusions. To clarify the research method, the following figure presents a schematic research design: 


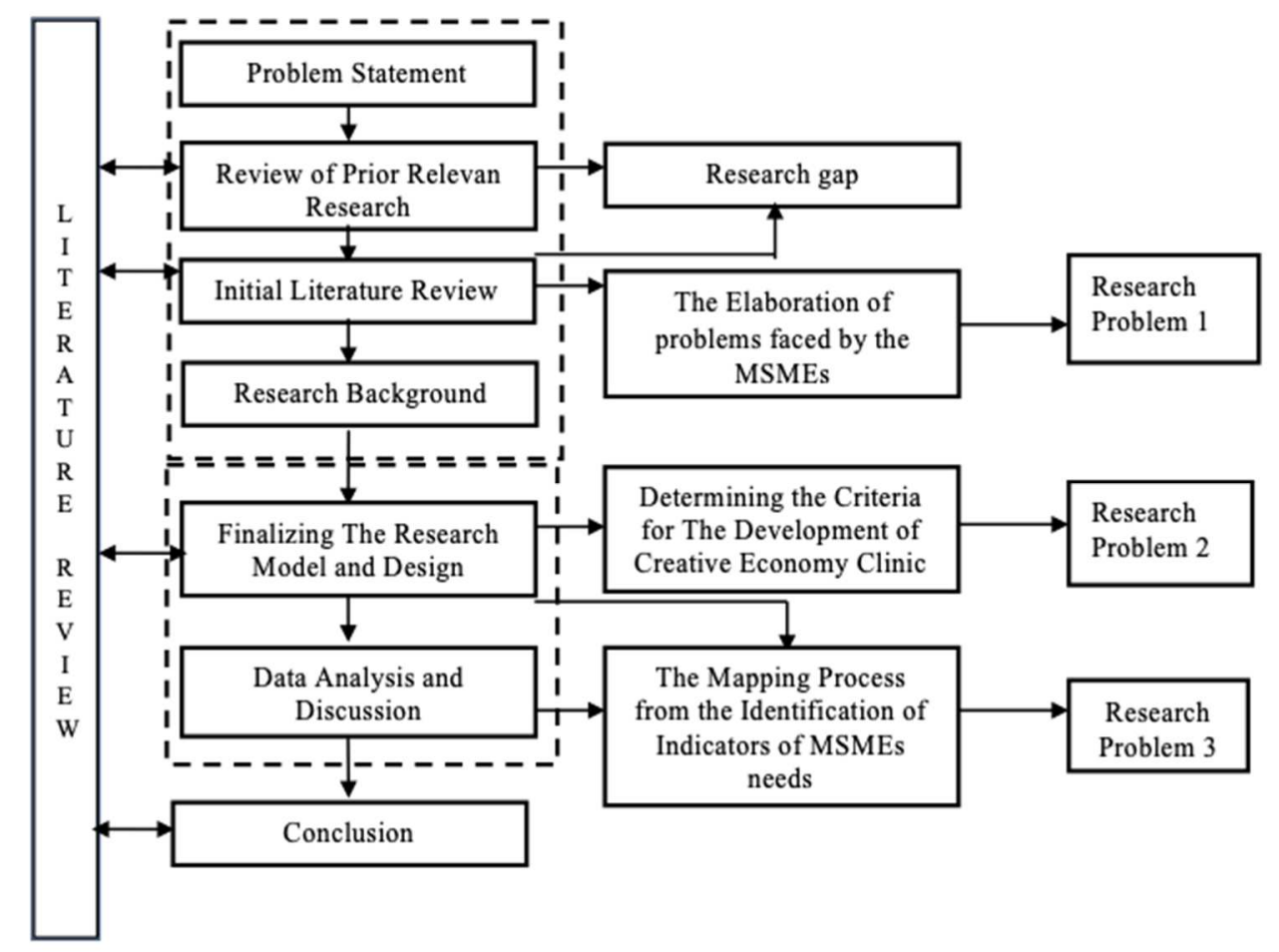

Fig 3. The Flow of Research Method

\section{Results and Disvussion}

\section{The Conceptual Model}

Why is the performance of Indonesia's MSMEs still relatively below their peers in neighboring countries that have relatively the same level of economic development? Based on the analysis of literature, secondary data, and input from several relevant ministries as policy implementers, business associations, the national banking industry, and other private parties, it can be concluded that many factors influence the competitiveness of MSMEs. These factors are divided into internal and external factors. Internal factors include aspects that determine the company's internal competitiveness such as productivity and innovation. Meanwhile, various external factors also influence and support the competitiveness of MSMEs, namely: the ease of doing business in Indonesia, financial and capital access, market access, infrastructure, and general macroeconomic conditions [27].

Internal and external variables relevant to the activities of MSMEs can be used as a basis for determining the criteria for the establishment of an effective creative economy clinic. Firstly, the creative economics clinic must be able to provide innovation development for MSME entrepreneurs. The academia as the initiator of the formation of this clinic must continue to conduct research and development in identifying new things related to innovations. This initiative is pivotal for creative economic actors who have gathered in the 
creative economy clinic [5]. Accordingly, in supporting comprehensive services, the creative economy clinic must be supported by professional and competent consultants in their fields. Lastly, high-quality clinical services require a transparent culture, involvement, and openness between the parties involved.

In the initial stages of developing a creative economy clinical model, a preliminary study of the identification of MSME requirements is needed. The mapping of indicators that are used in identifying the needs of MSMEs in Medan is as follows:

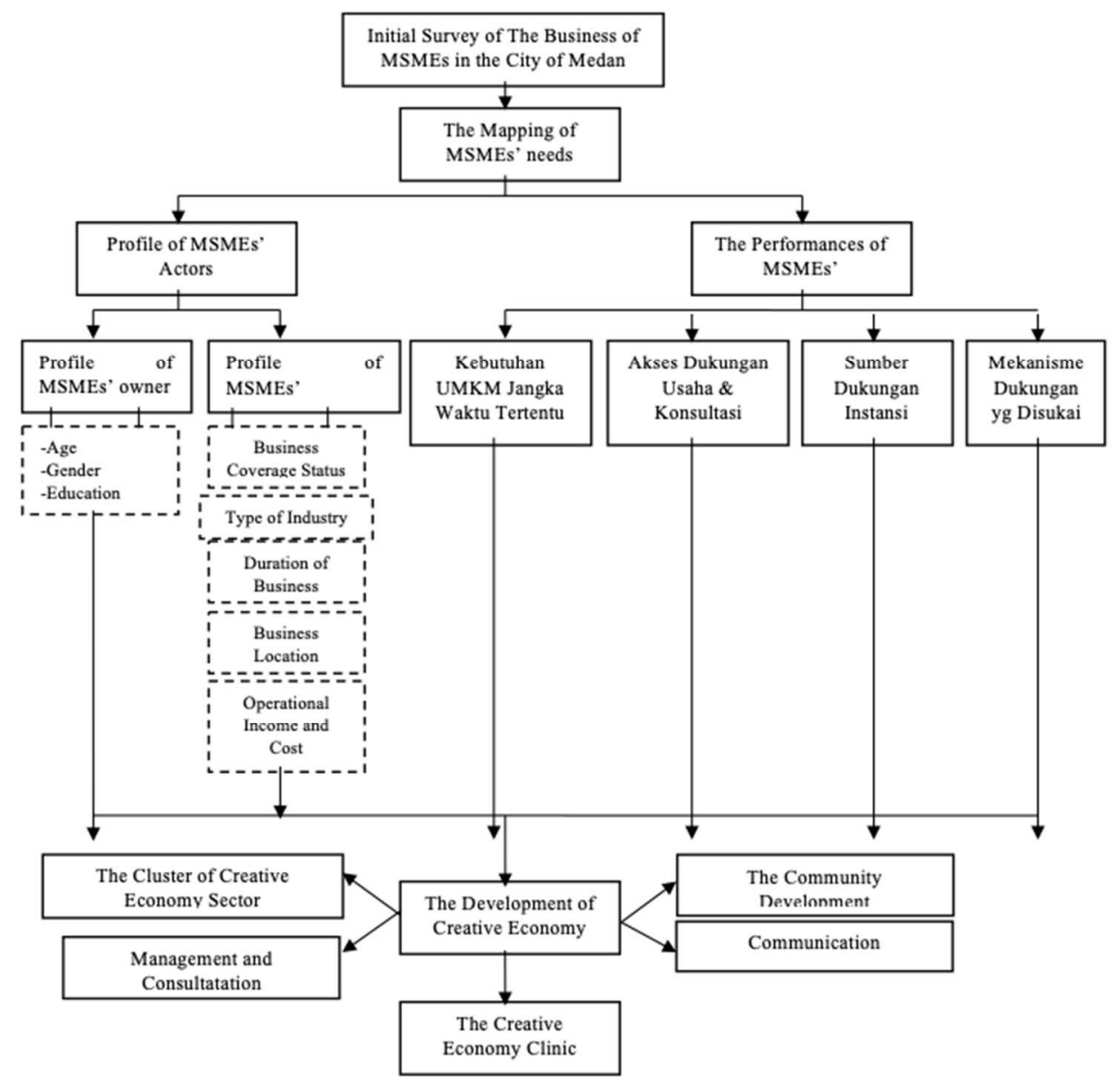

Fig 4. The Mapping of MSMEs Needs' related Indicators

The mapping of the indicators above is based on the theory put forward by Christian Grönroos in formulating the Know Yours Customers (KYC) strategy, which is one of the service strategies used to provide excellent service for service users by recognizing the needs and desires of those service users. The KYC strategy in public services is used to recognize the needs, interests, and aspirations of service users so that service delivery is responsive [28]. 

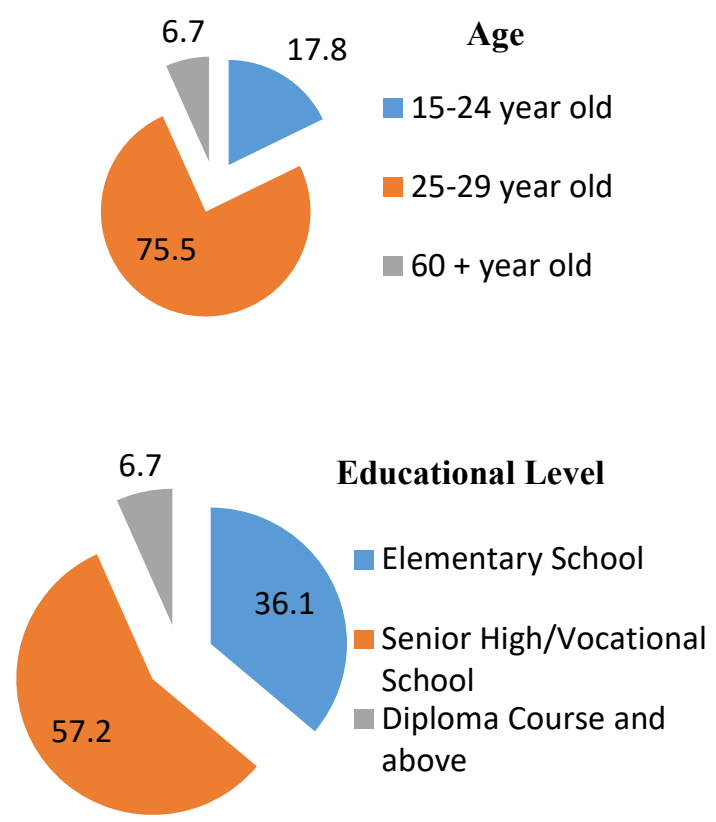

Data shows that in 2016 there is no difference in terms of the age of the creative economy workforce with their general counterparts. The participation of young people in this sector is 17.8 percent. On the other hand, the education structure of the creative economy workforce is different from the structure of the workforce in general. This sector still needs additional support from the higher educated generation. In 2016, the creative economy entrepreneurs dominated by women rated by 54.46 percent against men. This data experienced a slight increase from the previous year at 53.68 percent [2]. As indicated by Tambunan [29], the level of education has a positive effect on company growth. SME owners with higher levels of education are proven to have a better understanding of their business, for example, SMEs in the export-oriented rattan equipment sector. Besides, the ability of SME owners to understand the latest market trends is more influential on productivity compared to lack of expertise [27].

The identification of business scale and company age is important because the larger the scale of the business, the greater the opportunity to achieve an expected economic level of production. Thus, the structure of production costs can be reduced. A long-established company shows that the company already has the experience and competitiveness affecting its success in increasing production efficiency over time. Furthermore, labor training and the use of new technologies also play a large role in supporting productivity levels [27]. The phenomenon of the digital economy has been well implemented in the creative economy. The statistics provided by Bekraf and BPS indicate that creative economy entrepreneurs have been familiar with computers at 64.24 percent and use the internet at 68.83 percent.

However, in other regions outside Indonesia, the creative economy actors still have issues in maximizing the use of digital media. The openness that grows in society, especially 
in terms of the media, brings a positive impact on the growth of space for expression and creativity. Business location is also important in encouraging the development of the creative economy sector. The opportunity for an MSME to participate in the Global Value Chain (GVC) will be even greater if the business location is close to an industrial estate or port.

In the industrial revolution 4.0 era, the competitiveness of a business actor, especially MSMEs is also determined by the ease of access to business support. This phase is pivotal as additional capital is needed by MSMEs to successfully achieve the level of productivity needed following production demand. Financial institutions are expected to solve the issue in the course of a creative economy as they are the important elements to bridge the financial needs of actors in the creative economy [27]. Based on the results of the identification of MSME performance, especially in terms of MSME needs and the description of business support and business consultations obtained and the mechanism favored by MSME actors will provide a positive picture for LPPM Unimed in developing an effective creative economic clinical model while still paying attention to the concept of competent management, professional community empowerment, good communication and the formation of creative economic potential clusters as Switzerland, Germany, and Italy use cluster development strategies to encourage the MSME sector. The strategy begins with the identification of existing clusters and has the potential to become a strategic industry. This can be seen in the metal and machinery industry sector in Germany and the formation of high-tech industrial clusters (agglomeration) in Silicon Valley, United States [27].

\section{Conclusion}

The development of the creative economy must be set as an important agenda in building a national economy ecosystem, including in Indonesia. Various collaborative initiatives to improve the performance of the creative sector, especially MSMEs, still need to be done even though Indonesia is relatively late or not optimally utilizing these initiatives. The development of the concept of the creative economy in Indonesia that is currently running is a continuation of the application at the strengthening stage (2008-2014). At this time, the stages of the creative economy are in the direction of acceleration, which is the stage that is deliberately planned by the government so that the creative economy becomes one of the foundations and pillars and economic forces in Indonesia [27].

The role of universities is also important. Lecturers as researchers and community service professionals have conducted many research studies and have applied the results of studies to the community on a one-to-one approach (lecturer approach to MSME as partners). However, the existence of creative economy clinics or other institutions in universities is still not optimal in accelerating the development of the creative economy. This is caused by certain factors such as the resolution of MSME problems that are not holistic and sustainable due to the limitations of the ideal ecosystem and the non-optimal role of managers in carrying out their main tasks and functions as well as weak governance systems.

Based on that, LPPM Unimed developed a model of the creative economy clinic on campus. The analysis of the indicators related to the needs of MSMEs as an initial stage of developing the clinical model consists of the profile of the business owner, business profile, and business performance. The selection of indicators is based on a survey reference conducted on number of SME sector companies in the UK surveying business performance, problem needs and factors that inhibit the growth of SMEs [15]. 


\section{References}

[1] Nugroho, M. T. Industri Kreatif Berbasis Budaya Peluang dan Tantangan di Era Industry 4.0. Seminar Nasional IENACO. 430-436. (2019).

[2] Badan Ekonomi Kreatif. Laporan PDB Ekonomi Kreatif Tahun 2014-2016. Kerjasama Badan Pusat Statistik. (2017).

[3] Purnomo, R. A. Ekonomi Kreatif Pilar Pembangunan Indonesia. Surakarta: Ziyad Visi Media. (2016).

[4] Sitepu, E. S. Analisis Potensi dan Pengembangan Ekonomi Kreatif di Kota Medan. ResearchGate. 1-6. (2016)

[5] Dwihantoro, P. \& Lokantara, I. G. W. Konsep "Studio Kreatif” Media Akselerasi Pertumbuhan Ekonomi Kreatif Di Kabupaten Kendal. Jurnal Bakti Masyarakat Indonesia. 1(1), 83-9. (2018).

[6] Badan Ekonomi Kreatif. Infografis Ringkasan Data Statistik Ekonomi Kreatif Indonesia. Kerjasama Badan Pusat Statistik. (2017).

[7] Florida, R., Gates, G., Knudsen, B., \& Stolarick, K. The University and The Creative Economy. New York. (2006).

[8] Alexander, U., \& Eugeniy, P. The Entrepreneurial University in Russia: From Idea to Reality. $10^{\text {th }}$ Triple Helix Conference. Procedia-Social and Behavioural Sciences. 52(2012), 45-51. (2012)

[9] Feller, I. Universities as Engines of R\&D-Based Economic Growth: They Think They Can. Research Policy. 19(4), 335-348. (1990).

[10]David, P. The Knowledge Factor: A Survey of Universities. The Economist, 4 October. (1997).

[11] Gibbons, J. The Role of Stanford University: A Dean's Reflections. In The Silicon Valley Edge: A Habitat for Innovation and Entrepreneurship.Stanford University Press. (2000).

[12]Nicolaides, A. Entrepreneurship The Role of Higher Education in South Africa. Educational Research. 2(4), 1043-1050. (2011).

[13]Kasim, R.S.R. Malaysian Higher Education Institutions: Shaping an Entrepreneurial Agenda. International Journal of Information and Education Technology. 1 (2), 163 170. (2011).

[14]Faggian, A., Comunian, R., Jewell, S. \& Kelly, U. Bohemian Graduates in The UK: Disciplines and Location Determinants of Creative Careers, Regional Studies. 47(2), 183-200. (2013).

[15]Darwish, S. The Role of Universities in Developing Small and Medium Enterprises (SMEs): Future Challenges for Bahrain. International Business and Management. 8(2), 70-77. (2014).

[16]Ghina, A. Effectiveness of Entrepreneurship Education in Higer Education Institutions. Procedia Social and Behavioral Sciences. 332-345. (2014). 
[17]Comunian, R., Gilmore, A., \& Jocobi, S. Higher Education and The Creative Economy: Creative Graduates, Knowledge Transfer and Regional Impact Debates. ResearchGate. (2015).

[18]Bomani, M., Fields, Z., \& Derera, E. The Role of Higher Education Institutions in the Development of SMEs in Zimbabwe. International Journal of Business and Management Studies. 11(2), 1-15. (2019).

[19]Widiastuti, L. Jaringan Sosial Kota Pekalongan sebagai Modal Dukungan Perwujudan Kota Kreatif. Bandung: Program Studi Perencanaan Wilayah dan Kota ITB. (2016).

[20]Dinas Koperasi dan UKM Provinsi Sumatera Utara. Laporan Program Pengembangan Koperasi dan UKM Provinsi Sumatera Utara. (2018).

[21]Etzkowitz, H, Leydesdorff, L. The Dynamics of Innovation: From National System and 'Mode 2' to a Triple Helix of University Industry Goverment Relations, Research Policy. 29(2), 109-123. (2000).

[22]Plechero, M. The Role of Local Universities in Improving Traditional SMEs Innovative Performances: The Veneto Region Case. (2011).

[23]Piterou, A. \& Birch, C. The Role of Higher Education Institutions in Supporting Innovation in SMEs: University Based Incubators and Student Internships as Knowledge Transfer Tools. The Journal of Innovation Impact. 7(1), 72-79. (2014).

[24]Nuraini \& Nasri. R. Strategi Pengembangan Industri Kreatif dengan Pendekatan Triple Helix (Studi Kasus pada Industri Kreatif di Tangerang Selatan). Prosiding Seminar Nasional Riset Manajemen \& Bisnis 2017 "Perkembangan Konsep dan Riset E-Business di Indonesia”. 867-877. (2017).

[25]O'Malley, B. Universities Playing 'Key Role' in Growth of Start-Ups. University World News. 398. (2016).

[26]Gibb, A., Hoffer, A.R. \& Koffen, M. The entrepreneurial higher education institution: A review of the concept and its relevance today. Heinnovate, https://heinnovate.eu/intranet/tef/downloads/HEInnovate Analytical\%20paper.pdf. Diakses 12/11/ 2019.(2013).

[27] Sari, Y. R., et al. Pemetaan dan Strategi Peningkatan Daya Saing UMKM dalam Menghadapi MEA 2015 dan Pasca MEA 2025. Bank Indonesia. (2015).

[28]Rofida, Y. A. Strategi Pelayanan Pada Klinik ( Umkm ) Usaha Mikro, Kecil Dan Menengah Dinas Koperasi Provinsi Jawa Timur. Skripsi. Universitas Negeri Surabaya: Surabaya. (2018).

[29] Tambunan, H.T.T. SMEs in Developing Countries. Palgrave MacMillan, New York. http://dx.doi.org/10.1057/9780230250949. (2009).

[30]Maria, A. A. O. Questionnaire: National Survey On Smes Situation In The Philippines. ResearchGate. 1-12. (2016). 